\title{
KEANEKARAGAMAN JENIS DAN STRUKTUR TEGAKAN DI AREAL TEGAKAN TINGGAL
}

\author{
Herianto \\ Heriantotito@gmail.com \\ Staf Pengajar Jurusan Kehutanan Fakultas Pertanian Universitas Palangka Raya
}

\begin{abstract}
Logging activities have an impact on changes in composition and standing structure, tree species distribution, community similarity and species diversity. This study aims to determine the diversity of structures and standing composition of logged-over forests. The results show that the composition and structure of the stands are ecologically different, which is indicated by the low type of species equality index. The types of stands at the level of seedlings, stakes, columns and trees from each location are almost all different. But there are some of the same types encountered dominating on the locations of 2005, 2010 and 2015 such as Shorea leprosula, Dipterocarpus borneensis, Shorea laevis, Litsea sp. The stand density at the 2005 block location is higher than the two sites in 2010 and 2015, while the location of 2015 is the location with the lowest stand density.
\end{abstract}

Keywords: density, diversity, composition, standing structure.

\section{ABSTRAK}

Kegiatan penebangan berdampak pada perubahan komposisi dan struktur tegakan, penyebaran jenis pohon, kesamaan komunitas dan keragaman jenis. Penelitian ini bertujuan untuk mengetahui keragaman struktur dan komposisi tegakan pada hutan bekas tebangan. Hasil penelitian menunjukkan bahwa komposisi dan struktur tegakan secara ekologi berbeda, yang ditunjukkan dengan nilai indeks kesamaan jenis yang rendah. Jenis-jenis penyusun tegakan pada tingkat semai, pancang, tiang dan pohon dari tiap-tiap lokasi hampir semua berbeda. Namun ada beberapa jenis yang sama ditemui mendominasi pada lokasi tahun 2005, 2010 dan 2015 seperti Shorea leprosula, Dipterocarpus borneensis, Shorea laevis, Litsea sp. Kerapatan tegakan di lokasi blok 2005 lebih tinggi dibanding dengan kedua lokasi tahun 2010 dan 2015, sementara lokasi 2015 adalah lokasi dengan kerapatan tegakan paling rendah.

Kata kunci: kerapatan, keragaman, komposisi, struktur tegakan.

\section{PENDAHULUAN}

Hutan merupakan kesatuan ekosistem dengan berbagai komponen sumberdaya alam hayati beserta alam lingkungannya yang tidak dapat dipisahkan satu dengan yang lainnya. Berbagai macam komponen yang saling terkait dalam hutan menjadikan hutan sebagai obyek yang kompleks dan tidak mudah untuk dikelola. Padahal, hutan mampu memberikan manfaat secara lestari apabila dikelola dengan sistem yang benar. Sistem pengelolaan hutan akan terwujud apabila pengelolaan hutan dilakukan secar berkelanjutan atau Sustainable Forest Management (SFM).
Prinsip dari pengelolaan hutan berkelanjutan adalah adanya keseimbangan antara fungsi ekonomi, fungsi ekologi dan fungsi sosial hutan, yang dicirikan dengan produksi hasil hutan yang berkesinambungan tanpa banyak menyebabkan penurunan nilai dan produktivitas serta pengaruh yang merugikan lingkungan fisik dan sosial. Untuk mencapai keseimbangan ketiga aspek tersebut tentunya dibutuhkan perencaaan jangka panjang yang matang. Dalam penyusunan perencanaan diperlukan data dan informasi tentang perilaku tegakan 
hutan, karakteristik fisik hutan, struktur tegakan hutan, komposisi tegakan dan dinamikanya dari waktu ke waktu.

Informasi tentang struktur tegakan yang meliputi tingkat pertumbuhan pohon, penyusunnya, dan dinamika populasi jenis maupun kelompok jenis, sangat penting untuk diketahui sebagai dasar pengelolaan tegakan. Informasi ini dapat dipelajari dengan beberapa cara, antara lain dengan sebaran umur dan kelas tajuk dan dengan sebaran diameter tegakan.

Sebaran diameter tegakan merupakan faktor potensial namun sederhana untuk dapat menggambarkan sifat-sifat pohon dalam tegakan hutan. Perhitungan sebaran diameter erat hubungannya dengan tempat tumbuh, komposisi tegakan, umur dan kerapatan tegakan sangat berguna untuk tujuan ekonomi dan biologi (Sadono, 1988). Diameter merupakan karakteristik tegakan yang mudah pengukurannya dan memiliki korelasi yang kuat dengan parameter penting yang lain, seperti luas bidang dasar dan volume batang, selain itu diameter juga merupakan fungsi dari umur, dan kerapatan tegakan (Soerianegara, 2005).

Bentuk yang umum dari distribusi kelas diameter pada hutan alam berbentuk kurva "J terbalik" yang berarti bahwa jumlah pohon per satuan luas pada tingkat semai, pancang, tiang dan pohon berturut-turut semakin sedikit, sehingga permukaan yang ada mampu mendukung kekosongan dari stadium pertumbuhan di atasnya.
Keberhasilan tanaman untuk tumbuh pada tingkat semai, pancang, tiang dan pohon akan menjamin kelestarian produksi di waktu yang akan datang. Apabila tegakan tinggal yang tersedia ternyata tidak mampu tumbuh mencapai diameter yang cukup untuk ditebang, bisa beresiko pada turunnya volume panenan untuk rotasi berikutnya. Untuk memastikan kondisi tegakan tinggal yang ada perlu diamati struktur tegakan horizontal pada areal bekas tebangan pada jangka waktu tertentu.

\section{METODE PENELITIAN}

\section{Lokasi Penelitian}

Penelitian dilaksanakan di areal PT. Sarmiento Parakantja Timber (PT. Sarpatim) yang memiliki Ijin Usaha Pemanfaatan Hasil Hutan Kayu di Hutan Alam (IUPHHK-HA) termasuk wilayah Kabupaten Kotawaringin Timur Kalimantan Tengah. Secara geografis terletak antara 11200' - 112029' Bujur Timur dan 10023' - 2o26' Lintang Selatan. Areal penelitian terletak pada blok tanam tahun 2005, 2010 dan 2015, hutan yang dikelola termasuk hutan sekunder yang termasuk pada tebangan rotasi kedua. Areal kerja IUPHHK PT. Sarpatim terletak pada ketinggian $18-94 \mathrm{~m}$ dpl, secara umum topografi areal kerja didominir oleh kelas lereng A (datar) dengan kelerengan 0$8 \%$

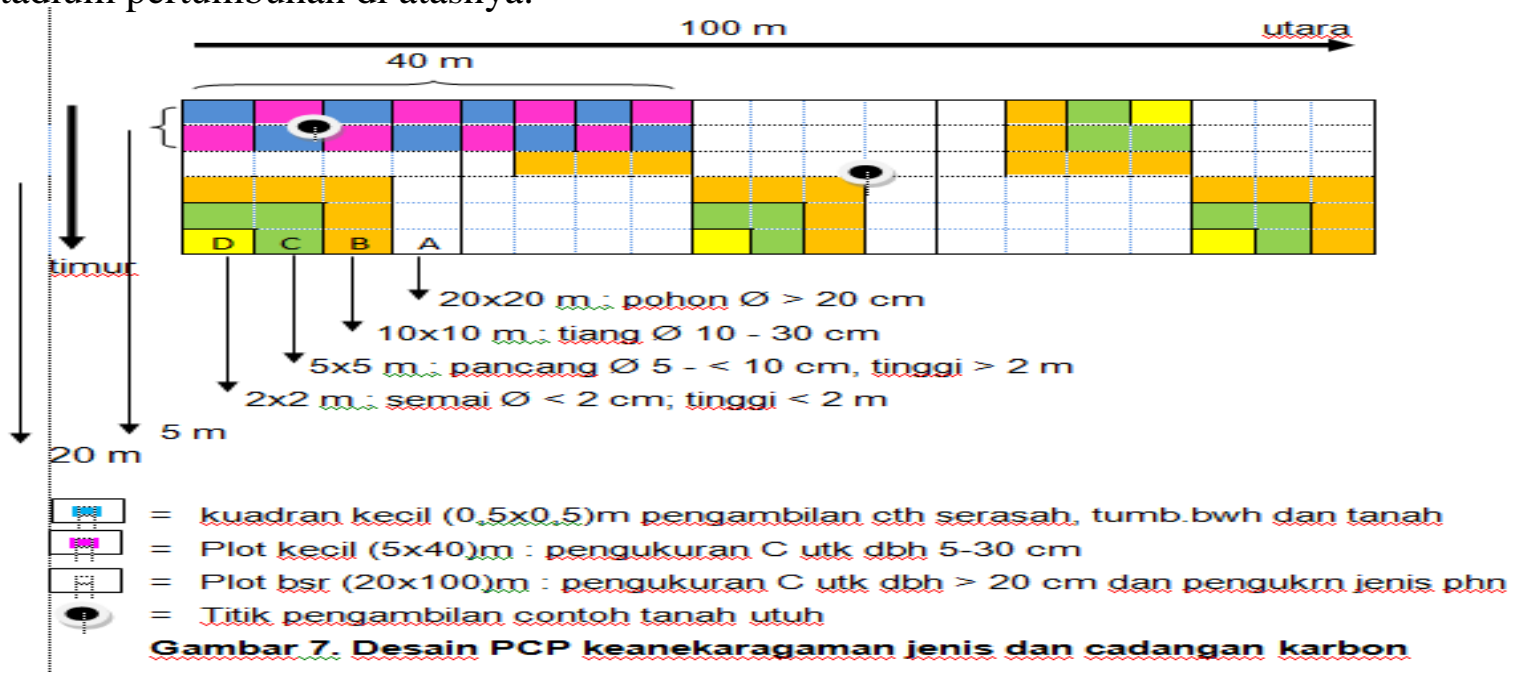


Pengambilan data analisis vegetasi tegakan berdasarkan tingkatan pertumbuhan mengacu pada Standar Nasional Indonesia (SNI 7724, 2011), pengumpulan data lapangan untuk keragaman jenis peneliti melakukan inventarisasi menggunakan metode kombinasi (metode jalur dan metode garis berpetak) menurut Wijana (2014).

Menurut (Omoro et al, 2010), data hasil pengukuran analisis vegetasi kemudian dihitung Kerapatan (K), Kerapatan Relatif (KR), Frekuensi (F), Frekuensi Relatif (FR), Dominansi (D) dan Dominansi Relatif (DR). Selanjutnya dihitung Indek Nilai Penting (INP) tegakan tingkat pohon, tiang, pancang dan semai di masing-masing lokasi penelitian.

Kerapatan =

Eindividu suatu jenis luas petak contoh

Kerapatan Relatif $(\mathrm{KR}) \quad=$ $\frac{\text { kerapatan suatu jenis }}{\text { kerapatan seluruh jenis }} \times 100 \%$

Frekuensi $=$ $\frac{\sum \text { plot diketemukannya suatu jenis }}{\text { jumlah seluruh petak contoh }}$ Frekuensi Relatif (FR) $=$
$\frac{\text { Frekuensi dari suatu jenis }}{\text { Frekuensidari seluruh jenis }} \times 100 \%$

Dominansi/Luas penutupan tajuk = $\sum$ luas bidang dasar suatu jenis Luas petak contoh

Dominansi Relatif (DR) = $\frac{\text { Dominansi suatu jenis }}{\text { do minansidari seluruh jenis }} \times 100 \%$

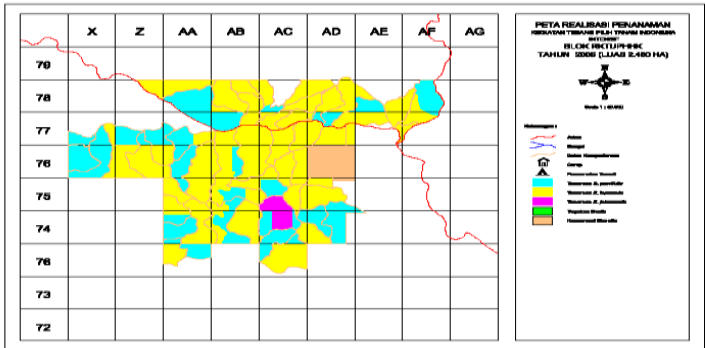

Blok 2005

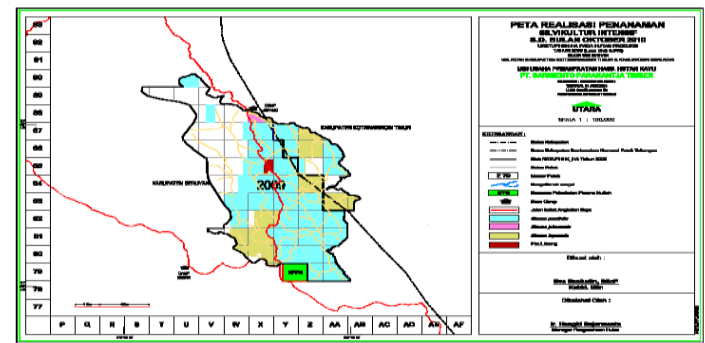

Blok 2010

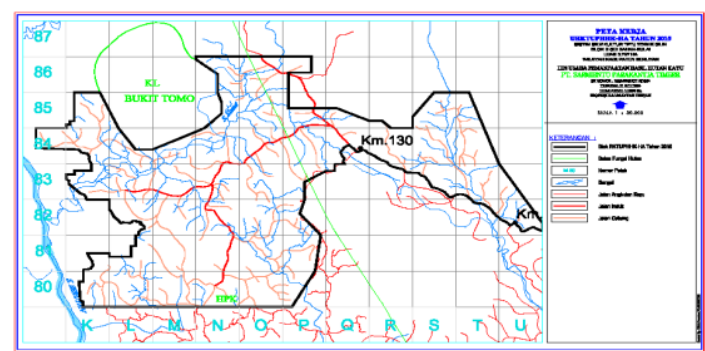

Blok 2010

Gambar 2. Lokasi Penelitian Tegakan Tinggal

Nilai INP adalah jumlah dari Kerapatan Relatif (KR), Frekuensi Relatif (FR) dan Dominansi relatif (DR). Analisis yang dipergunakan analisis kuantitatif untuk mengetahui pengaruh variabel bebas terhadap variabel terikat, dipergunakan regresi linier berganda yang dilanjutkan pengujian hipotesis dengan uji-F dan uji-t, dengan alat bantu Ms. Excel dan SPSS (Statistical Product and Service Solution) versi 25

\section{HASIL DAN PEMBAHASAN}

Struktur dan Komposisi Tegakan

Kondisi struktur tegakan vertikal pada masing-masing petak penelitian 
dengan kelas tinggi vegetasi masing-masing $<10 \mathrm{~m}, 11-20 \mathrm{~m}, 21-30 \mathrm{~m}, 31-40 \mathrm{~m}$ dan $>40$ $\mathrm{m}$ cenderung mengalami penurunan dalam jumlah vegetasi per satuan luas lahan, kondisi hutan memiliki variasi penyebaran pohon berdasarkan kelas ketinggiannya. Menunjukan bahwa semakin tinggi ukuran pohon maka semakin berkurang jumlah pohon tersebut. Hal ini sesuai dengan pernyataan Saridan dan Soegiharto (2011) yang menyatakan bahwa jumlah vegetasi dalam hutan alam berbanding terbalik dengan tinggi, yaitu semakin tinggi vegetasi hutan semakin sedikit jumlahnya.
Struktur tegakan vertikal pada petak penelitian tahun 2005, tahun 2010 dan tahun 2015 menunjukkan karakteristik menyerupai huruf "J" terbalik. Menurut Baker et al (1987), Lamprecht (1989) dan Nyland (1996) hutan semua umur (unaged forest) yang normal dan sehat mempunyai Struktur yang membentuk huruf "J" terbalik. Dengan demikian kondisi tegakan hutan pada areal penelitian masih dalam kondisi normal dan sehat.

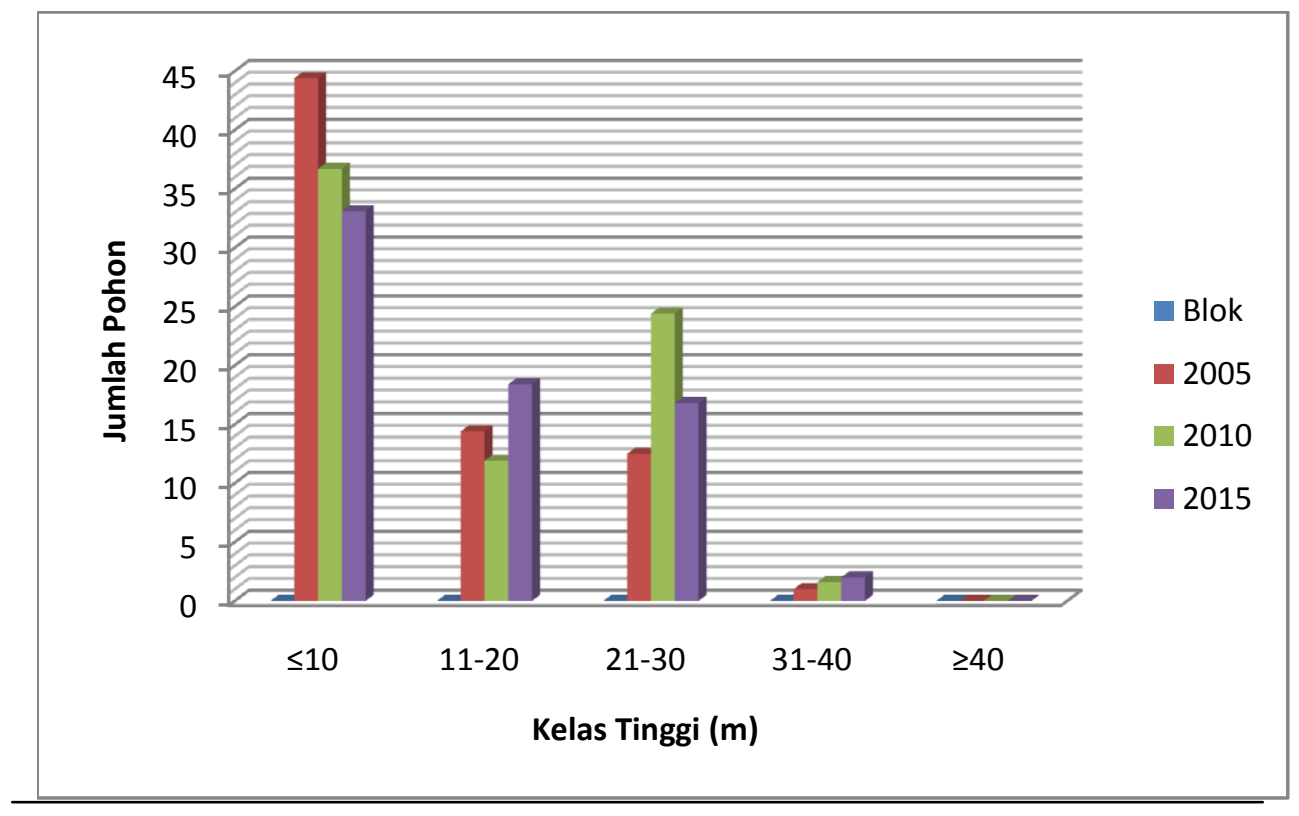

Gambar 3. Struktur dan Komposisi Tegakan

Berdasarkan klasifikasi stratum dalam hutan menurut Soerianegara dan Indrawan (1980), maka hasil penelitian di lapangan menunjukkan bahwa sebelum dilakukan kegiatan pemanenan kayu terlihat bahwa strata tajuk terdiri dari 4 (empat) stratum/lapisan tajuk yaitu stratum A (tinggi total $>30 \mathrm{~m}$ ), stratum B (tinggi total 20-30 m), stratum C (tinggi total 4-20 m) .dan stratum D (tinggi 1-4 m) sedangkan setelah dilakukan kegiatan pemanenan kayu terdapat tegakan-tegakan yang rusak sehingga mengakibatkan perubahan (penurunan) jumlah tegakan pada masingmasing stratum. Namun penurunan jumlah tegakan tersebut tidak mengakibatkan hilangnya stratum-stratum yang ada.

Pada stratum A hutan bekas tebangan, banyak ditemukan jenis yang belum komersial (lesser know species) seperti jambu-jambuan (Eugenia spp.), medang (Litsea spp.), pampaning (Quercus sp.), binuang (Octomeles sp.), bunyau (Santiria griffithii), kumpang (Horsfieldia 
crassifolia), mahawai (Cyathocalyx biovulatus), hal tersebut diduga karena jenis tersebut lebih mampu bersaing dengan individu jenis lainnya dalam hal memenuhi kebutuhan akan unsur hara, mineral, tanah, air, cahaya dan ruang tumbuh secara keseluruhan. Jens-jenis tersebut juga belum ditebang, sehingga keberadaannya masih banyak pada hutan bekas tebangan.

Struktur tegakan horizontal didasarkan pada hubungan antara kelas diameter dengan jumlah pohon pada masing-masing petak penelitian, yang dibagi dalam kelas diameter $<10 \mathrm{~cm}, 10-19,9 \mathrm{~cm}, 20-29,9 \mathrm{~cm}$, 30-39,9 cm, 40-49,9 cm, 50-59,9 c-n dan >_60 cm.
Menunjukkan bahwa ketiga areal bekas tebangan tersebut memiliki variasi sebaran pohon yang berbeda, dengan berbagai kelas diameter. Jumlah individu berdasarkan kelas diameter pada setiap kondisi hutan mengalami penurunan dari diameter kecil ke diameter besar. Penurunan jumlah individu yang terlihat paling menonjol terdapat pada kelas diameter $<10 \mathrm{~cm}$ ke kelas diameter 10-19.9 cm. Hal ini sesuai dengan pernyataan Saridan dan Soegiharto (2011) bahwa jumlah vegetasi dalam hutan alam berbanding terbalik dengan besar diameternya, yaitu semakin besar diameter pohon maka semakin sedikit jumlahnya.

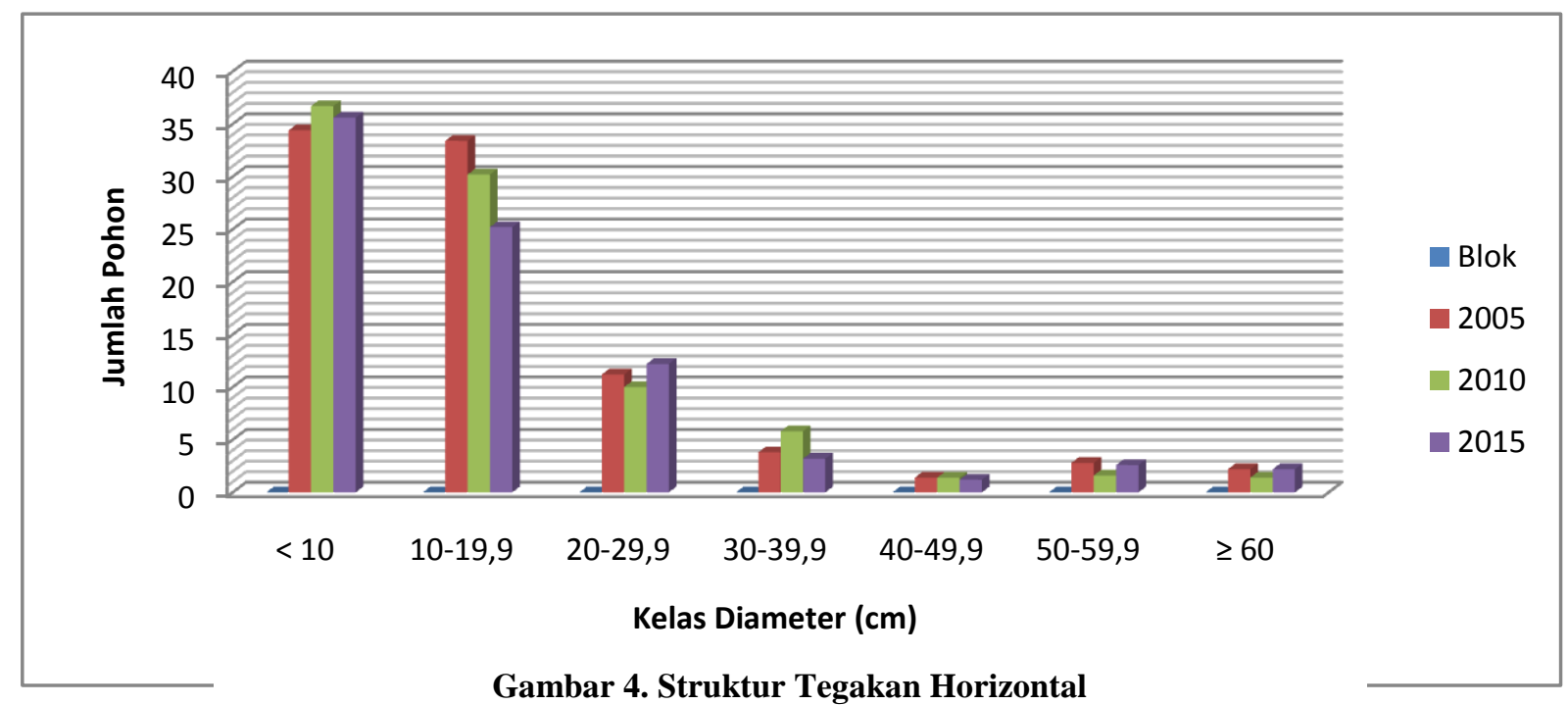

Struktur tegakan horizontal pada petak penelitian menunjukkan bahwa jumlah pohon yang semakin berkurang dari kelas diameter kecil ke kelas diameter besar, sehingga bentuk kurva yang dicirikan oleh jumlah sebaran menyerupai huruf "J" terbalik. Hal ini menunjukkan bahwa tegakan hutan pada .petak tersebut merupakan hutan tidak seumur yang relatif seimbang, dimana jumlah individu semakin berkurang dengan semakin besarnya ukuran diameter pohon.

Komposisi jenis pohon pada blok RKT tahun 2005 yang mendominasi seperti jenis meranti, bangkirai, banitan, benuas, bintangur, bunyau, kamasulan, kumpang, kayu arang, mahawai , medang, tengkawang, ubar, mahang, bunyau, jambujambu, dan pempaning. Komposisi jenis pada tahun 2010 yang mendominasi seperti jenis meranti, bangkirai, keruing, bintangur, bunyau, keruing, kopi hitam, kumpang arang, mahang, mahawai, medang, resak, dan ubar.

Komposisi jenis tahun 2015 yang mendominasi seperti jenis meranti, keruing, medang, jambu-jambu, bintangur, bunyu, hanyer bajai, kayu gahung, kayu asem, mahawai, pampaning, tehang, dan ubar.

Jumlah jenis pertumbuhan tingkat semai pada tahun 2005 terdiri dari 203 individu; pada tahun 2010 terdiri dari 
218 individu; dan tahun 2015 terdiri dari 208 individu. Jumlah jenis pertumbuhan tingkat pancang, pada thun 2005 terdiri dari 143 individu; pada tahun 2010 terdiri dari 154 jenis; dan tahun 2015 terdiri dari 129 individu. Jumlah jenis pertumbuhan tingkat tiang pada tahun 2005 terdiri dari 167 individu; pada tahun 2010 terdiri dari 278 individu; dan tahun 2015 terdiri dari 254 individu. Jumlah jenis pertumbuhan tingkat pohon pada tahun 2005 terdiri dari 108 individu; pada tahun 2010 terdiri dari 93 individu; dan tahun 2015 terdiri dari 108 individu.

Tabel 1. Nilai Kerapatan setiap Jenis Pada Tingkat Pertumbuhan

\begin{tabular}{|l|l|l|l|l|}
\hline \multirow{2}{*}{ Kondisi Tegakan } & \multicolumn{4}{|l|}{ Kerapatan Jenis (jenis/ha) } \\
\cline { 2 - 5 } & Semai & Pancang & Tiang & Pohon \\
\hline Tahun 2005 & 10.150 & 2.800 & 1.670 & 540 \\
\hline Tahun 2010 & 10.800 & 2.980 & 2.780 & 465 \\
\hline Tahun 2015 & 10.250 & 2.760 & 2.540 & 545 \\
\hline
\end{tabular}

Sumber : Hasil Penelitian, 2017

Tabel 2. Nilai Frekuensi Relatif setiap Jenis Pada Tingkat Pertumbuhan

\begin{tabular}{|l|l|l|l|l|}
\hline \multirow{2}{*}{ Kondisi Tegakan } & Frekuensi Relatif $(\%)$ & Tiang & Pohon \\
\cline { 2 - 5 } & Semai & Pancang & 4,00 & 3,03 \\
\hline Tahun 2005 & 4,76 & 2,88 & 2,22 & 3,85 \\
\hline Tahun 2010 & 3,13 & 2,87 & 2,56 & 2,42 \\
\hline Tahun 2015 & 2,63 & 2,52 & & \\
\hline
\end{tabular}

Sumber : Hasil Penelitian, 2017

Tabel 3. Nilai Dominansi setiap Jenis Pada Tingkat Pertumbuhan

\begin{tabular}{|l|l|l|l|}
\hline \multirow{2}{*}{ Kondisi Tegakan } & Dominansi (m2/ha) & \\
\cline { 2 - 4 } & Pancang & Tiang & Pohon \\
\hline Tahun 2005 & 1,40 & 11,48 & 45,87 \\
\hline Tahun 2010 & 1,49 & 13,74 & 30,93 \\
\hline Tahun 2015 & 3,28 & 18,77 & 44,97 \\
\hline
\end{tabular}

Sumber : Hasil Penelitian, 2017

Tabel 4. Indeks Keanekaragaman Shanon-Wiener $\left(\mathrm{H}^{\prime}\right)$ Pada Tingkat Pertumbuhan

\begin{tabular}{|l|l|l|l|l|}
\hline \multirow{2}{*}{ Kondisi Tegakan } & \multicolumn{4}{l|}{ Indek Keanekaragaman Jenis $(\mathrm{H})$} \\
\cline { 2 - 5 } & Semai & Pancang & Tiang & Pohon \\
\hline Tahun 2005 & 2,34 & 3,07 & 2,61 & 2,63 \\
\hline Tahun 2010 & 2,63 & 3,00 & 2,88 & 2,67 \\
\hline Tahun 2015 & 2,81 & 3,12 & 2,91 & 3,21 \\
\hline
\end{tabular}

Sumber : Hasil Penelitian, 2017

Karakter ekologi yang meliputi kerapatan tegakan, indeks kesamaan komunitas, indeks keragaman jenis dan kemerataan jenis digunakan untuk membandingkan komunitas tegakan pada ketiga lokasi. Hal ini bertujuan untuk melihat atau membandingkan komunitas tegakan ketiga lokasi apakah terdapat perbedaan atau tidak. Kerapatan tegakan (jumlah pohon/ha) pada suatu komunitas merupakan salah satu faktor yang mempengaruhi keanekaragaman jenis selain kuantitas jenis 
dan tingkat penyebaran masing- masing jenis.

Berdasarkan hasil uji t menunjukkan bahwa terdapat perbedaan kerapatan tegakan pada masing- masing lokasi, antara ketiga lokasi yang mempunyai kerapatan tegakan yang berbeda satu dengan lainnya. Kerapatan tegakan tahun 2005, 2010 dan 2015 berbeda nyata. Hal ini diduga disebabkan oleh perbedaan kondisi biogeografis, serta intensitas tebangan (Petocz, 1987; Elias, 2002; Muller, 2005; Kartikasari dkk., 2012). Jumlah pohon dan struktur tegakan dapat menggambarkan tingkat ketersediaan tegakan pada setiap tingkat pertumbuhan tegakan, sehingga keduanya diduga berpengaruh terhadap kemampuan regenerasi atau pertumbuhan tegakan termasuk kecepatan pemulihan diri tegakan setelah mengalami gangguan yaitu perlakuan penebangan (Muhdin, 2012). Perbedaan kerapatan pada ketiga daerah tersebut bisa disebabkan oleh karakter tegakan masing-masing lokasi di mana karakter tersebut terkait dengan fisiologi tegakan dalam merespon perubahan lingkungan.

Indeks kesamaan komunitas menggambarkan tingkat kesamaan struktur dan komposisi jenis dari tegakan yang dibandingkan. Nilai indeks kesamaan berkisar $0-100 \%$, di mana semakin tinggi nilai indeks kesamaan jenis menunjukkan semakin tinggi pula tingkat kemiripan jenis antara dua komunitas.

Indeks keanekaragaman menunjukkan hubungan antara jumlah spesies dengan jumlah individu yang menyusun suatu komunitas (Heddy,1994). Untuk mengetahui tingkat kestabilan keanekaragaman jenis dapat digunakan nilai indeks keanekaragaman jenis ( $\left.\mathrm{H}^{\prime}\right)$. Indeks keanekaragaman jenis $\left(\mathrm{H}^{\prime}\right)$ menggambarkan tingkat kestabilan suatu komunitas tegakan. Semakin tinggi nilai H', maka komunitas vegetasi hutan tersebut semakin tinggi tingkat kestabilannya. Suatu komunitas yang memiliki nilai $\mathrm{H}^{\prime}<1$ dikatakan komunitas kurang stabil, jika nilai $\mathrm{H}^{\prime}$ antara 1-2 dikatakan komunitas stabil, dan jika nilai $\mathrm{H}^{\prime}>2$ dikatakan komunitas sangat stabil (Kent dan Paddy, 1992). Odum (1996) menyebutkan bahwa suatu komunitas memiliki nilai $\mathrm{H}^{\prime}<1$ dikatakan tingkat keanekaragaman rendah, $1 \leq \mathrm{H}^{\prime} \leq 3$ tingkat keanekaragaman sedang dan $H^{\prime}>3$ tingkat keanekeaneragaman tinggi.

Indeks kemerataan menggambarkan perataan penyebaran individu dari jenis organisme yang menyusun komunitas, dan menggambarkan kestabilan suatu komunitas. Untuk menilai kemantapan atau kestabilan jenis dalam suatu komunitas dapat digunakan nilai indeks kemerataan jenis (E). Semakin tinggi nilai E, maka keanekaragaman jenis dalam komunitas semakin stabil dan semakin rendah nilai E, maka kestabilan keanekaragaman jenis dalam komunitas tersebut semakin rendah (Soerianegara dan Indrawan, 1976; Odum, 1996).

Hasil perhitungan indeks keanekaragaman dan nilai kemerataan jenis pohon untuk masing-masing lokasi menunjukkan bahwa indeks keragaman (H') dan kemerataan jenis (E) pada ketiga lokasi sangat stabil $>2$. Nilai H' menunjukkan bahwa keragaman jenis pada hutan bekas tebangan di tiga lokasi tersebut sudah stabil dan mengarah pada hutan primer. Hal ini mengindikasikan bahwa pengaruh kegiatan tebangan pada ketiga lokasi tersebut sudah tidak nampak lagi. Nilai $H^{\prime}$ dapat digunakan untuk mengetahui pengaruh gangguan terhadap lingkungan atau untuk mengetahui tahapan suksesi dan kestabilan dari komunitas tumbuhan pada suatu lokasi. Kondisi ini menunjukkan bahwa populasi antara jenis pohon yang ada pada ketiga areal cukup merata sehingga tidak mudah mendapatkan gangguan serta mudah kembali ke keadaan semula.

Indeks kemerataan jenis tinggi berbanding lurus dengan indeks keanekaragaman jenis, di mana semakin 
tinggi nilai indeks kemerataan jenis maka nilai indeks keanekaragaman jenis juga akan semakin tinggi. Keanekaragaman jenis pohon yang tinggi pada lokasi tersebut menggambarkan ciri khusus hutan bekas tebangan di mana yang ditebang hanya jenis dan diameter tertentu sehingga keragaman masih tetap terjaga (Whitfeld dkk., 2014). Pertumbuhan tegakan untuk memperoleh ruang tumbuh vertikal juga menyebabkan lebih banyak jenis yang berkompetisi untuk memenuhi ruang vertikal tersebut, sehingga menyebabkan kerapatan individu menjadi tinggi (Laurans dkk., 2014).

Dominansi suatu jenis menggambarkan tingkat dominasinya terhadap jenis-jenis lain dalam suatu komunitas dan dapat dilihat dari ukuran indeks nilai penting (INP). Jenis-jenis yang mempunyai INP tertinggi berpeluang lebih besar untuk dapat mempertahankan pertumbuhan dan kelestarian jenisnya.

\section{Kesimpulan}

Hasil penelitian menunjukkan bahwa keanekaragaman komposisi dan struktur secara ekologi berbeda yang ditunjukkan dengan nilai indeks kesamaan jenis yang rendah. Selain itu, jenis-jenis penyusun tegakan pada tingkatan semai, pancang, tiang dan pohon dari tiaptiap lokasi hampir semua berbeda. Namun ada beberapa jenis yang sama ditemui mendominasi pada lokasi 2005 dan 2010 seperti Shorea parvifolia, Shorea leprosula, Calophyllum inophyllum, dan Dipterocarpus sp. Kerapatan tegakan di lokasi 2005 lebih tinggi dibanding dengan kedua lokasi 2010 dan 2015, sementara 2015 adalah lokasi dengan kerapatan tegakan paling rendah.

\section{DAFTAR PUSTAKA}

Baltzer, J.L., dan Thomas, S.C., 2010. A Second Dimension to The Leaf Economics Spectrum Predicts Edaphic Habitat Association in A Tropical Forest. PloS one, 5(10):e13163.

Duah-Gyamfi, A., Swaine, E.K., Adam, K.A., Pinard, M.A., dan Swaine, M.D., 2014. Can Harvesting for Timber in Tropical Forest Enhance Timber Tree Regeneration. Forest Ecology and Management, 314, 26-37.

Cordell, S., Hubbell, S.P., dan Sack, L., 2014. Trade-offs in Seedling Growth and Survival Within and Across Tropical Forest Microhabitats. Ecology and Evolution, 4(19):3755-3767.

Iwan, H., 2012. Komposisi Jenis dan Struktur Tegakan pada Areal Bekas Tebangan di PT Salaki Summa Sejahtera, Provinsi Sumatera Barat. Jurnal Silvikultur Tropika, 3(3):155-160.

Kenfack, D., Chuyong, G.B., Condit, R., Russo, S. E., dan Thomas, D.W., 2014. Demographic Variation and Habitat Specialization of Tree Species in A Diverse Tropical Forest of Cameroon. Forest Ecosystems, 1(1):1-13.

Laurans, M., Hérault, B., Vieilledent, G., dan Vincent, G., 2014. Vertical Stratification Reduces Competition for Light in Dense Tropical Forests. Forest Ecology and Management, 329:79-88.

Mawazin, dan Subiakto, A., 2013. Keanekaragaman dan Komposisi Jenis Permudaan Alam Hutan Rawa Gambut Bekas Tebangan di Riau. Indonesian Forest Rehabilitation Journal, 1(1):59-73.

Muhdin, E., Suhendang, D., Wahjono, H., Purnomo, Istomo, dan Simangunsong, B.C.H., 2008. Keragaman Struktur Tegakan Hutan Alam Sekunder. J. Man. Hut. Trop., 16(2):81-87.

Odum, E.P., $1996 . \quad$ Dasar-dasar Ekologi (T. Samingan, Terjemahan). Yogyakarta: Gadjah Mada University Press. 
Sidiyasa, K., 2012. Karakteristik Hutan Rawa Gambut Di Tuanan Dan Katunjung, Kalimantan Tengah. Jurnal Penelitian Hutan dan Konservasi Alam, 9(2):125-137.

Smith, B., dan Wilson, J.B., 1996, A Consumer's Guide To Evenness Indices, Oikos, 70-82. Smith, R.G.B., and Nichols. J.D., 2005. Patterns of Basal Area Increment, Mortality and Recruitment were Related to Logging Intensity in Subtropical Rainforest in Australia over 35 years. Forest Ecol. Manag., 218:319328.

Spellerberg, I.F., dan Fedor, P.J., 2003, Atribute to Claude Shannon (1916-2001) And A Plea For More Rigorous Use Of Species Richness, Species Diversity and The 'Shannon- Wiener'Index, Global Ecology and Biogeography, 12(3):177-179. Whitfeld, T.J., Lasky, J.R., Damas, K., Sosanika, G., Molem, K., dan Montgomery, R.A., 2014. Species Richness, Forest Structure, and Functional Diversity during Succession in the New Guinea

Lowlands. Biotropica, 46(5):538-548 